\title{
The impact of microRNA-mediated PI3K/AKT signaling on epithelial-mesenchymal transition and cancer stemness in endometrial cancer
}

\author{
Peixin Dong ${ }^{1 *}$, Yosuke Konno ${ }^{2}$, Hidemichi Watari ${ }^{2}$, Masayoshi Hosaka ${ }^{2}$, Masayuki Noguchi ${ }^{3}$ and Noriaki Sakuragi ${ }^{1,2}$
}

\begin{abstract}
Activation of the PI3K/AKT pathway, a common mechanism in all subtypes of endometrial cancers (endometrioid and non-endometrioid tumors), has important roles in contributing to epithelial-mesenchymal transition (EMT) and cancer stem cell (CSC) features. MicroRNAs (miRNAs) are small non-coding RNA molecules that concurrently affect multiple target genes, and regulate a wide range of genes involved in modulating EMT and CSC properties. Here we overview the recent advances revealing the impact of miRNAs on EMT and CSC phenotypes in tumors including endometrial cancer via regulating PI3K/AKT pathway. MiRNAs are crucial mediators of EMT and CSC through targeting PTEN-PI3K-AKT-mTOR axis. In endometrial cancer cells, miRNAs can activate or attenuate EMT and CSC by targeting PTEN and other EMT-associated genes, such as Twist1, ZEB1 and BMI-1. More detailed studies of miRNAs will deepen our understanding of the molecular basis underlying PI3K/AKT-induced endometrial cancer initiation and progression. Targeting key signaling components of PI3K/AKT pathway by restoring or inhibiting miRNA function holds promise as a potential therapeutic approach to suppress EMT and CSC in endometrial cancer.
\end{abstract}

Keywords: Microrna, PI3K, PTEN, AKT, mTOR, EMT, Invasion, Cancer stem cell, Chemoresistance, Endometrial cancer

\section{Introduction}

Endometrial cancer (EC) is the most common invasive neoplasm of the female genital tract in the United States and many other developed countries. In 2014, there are about 52630 new cases and 8590 deaths due to this neoplasm [1]. Although Asian women have a lower risk of EC compared to those in the US and other western countries, the incidence of EC in Shanghai and in Japan has substantially increased $[2,3]$.

A dualistic model of EC has been proposed, broadly classified into type 1 (approximately $75 \%$ of cases, endometrioid EC) and type 2 non-endometrioid tumors (serous and clear-cell histology) [4]. Most type 1 ECs are usually diagnosed early and have a good prognosis [5]. Type II ECs tend to invade surrounding tissue and metastasize, with a lower 5-year survival rate [5-8]. At the molecular level, type 1 ECs often show PTEN loss and mutations in PI3KCA and KRAS [9-12], and type 2

\footnotetext{
* Correspondence: dpx1cn@gmail.com

'Department of Women's Health Educational System, Hokkaido University School of Medicine, Hokkaido University, N15, W7, Sapporo 0608638, Japan Full list of author information is available at the end of the article
}

cancers commonly exhibit mutations in $p 53$ [13] and HER-2 overexpression [14].

However, this model has been challenged by the findings that many tumors actually show combined or overlapping clinical, pathological and molecular features of both classification types $[15,16]$, suggesting that a common molecular mechanism involved in both types of cancers may exist. Consistent with this, recent molecular researches have shown that dysregulation of the PI3K/ AKT signaling was found in all subtypes of EC, and associated with more aggressive disease [17-19]. Therefore, effective blocking of the PI3K/AKT pathway may be therapeutically valuable in the treatment of EC.

The epithelial-mesenchymal transition (EMT) program plays important roles in promoting tumor cell invasion, chemoresistance and cancer stem cell (CSC) properties $[20,21]$. Accumulating genetic and cancer biology evidence demonstrate that PI3K/AKT pathway is a central mechanism controlling EMT/CSC features, despite its definite effects on cancer cell proliferation and survival [22-25]. For example, activation of PI3K/AKT pathway was detected in radioresistant prostate cancer cells with 
enhanced EMT/CSC phenotypes, and the combination of PI3K inhibitor with radiotherapy induced more apoptosis in radioresistant cells, along with decreased expression of EMT/CSC markers and PI3K/AKT signaling proteins [26]. Squamous cell carcinoma lines expressing an active form of AKT produce a transcription factor Snail, which is known to promote EMT via the repression of E-cadherin gene [27].

MicroRNAs (miRNAs) are small non-coding RNA molecules that post-transcriptionally control the translation and stability of mRNAs. Individual miRNA can concurrently bind to multiple mRNAs and affect their expression [28]. Loss of tumor suppressive miRNAs and/or gain of oncogenic miRNAs lead to tumorigenesis and progression. In the last decade or so, miRNAs have emerged as key regulators of a wide range of genes and signals involved in modulating EMT/CSC properties, such as the PI3K/AKT pathway $[29,30]$.

In this review, we highlight the recent advances unraveling novel roles of miRNAs in the regulation EMT/CSC phenotypes of tumor cells through targeting PI3K/AKT pathway, focusing on the potential impact of miRNAs on EMT/CSC characteristics of EC cells via targeting this pathway.

\section{Activation of PI3K/AKT signaling promotes EMT and CSC in EC}

Among three classes of PI3Ks, only classes IA PI3Ks are found to be involved in human cancers [31]. PI3K is a dimeric enzyme and consist of regulatory p 85 and catalytic subunit p110 subunits [32]. Numerous important mechanisms for PI3K/AKT activation include activated receptor tyrosine kinase (RTK), RTK-induced KRAS activation, and genetic abnormalities in specific component of the pathway, such as loss of PTEN tumor suppressor (through deletion, gene methylation and protein stability) and PI3KCA (p110 $\alpha)$ mutation or gene amplification $[33,34]$. The AKT kinase family has three highly homologous isoforms: AKT1, AKT2 and AKT3 [35]. Studies in breast cancer and EC cells have identified contradictory effects of AKT1 and AKT2 on cancer cell motility [36-38]. The mammalian target of rapamycin (mTOR) is a critical regulator that controls cell growth, proliferation, migration and invasion through two complexes, mTORC1 and mTORC2 $[39,40]$. Although activated PI3K/AKT pathway promotes mTORC1 activation, mTORC1 hyperactivation also leads to feedback inhibition of the PI3K/AKT signaling [20] (Figure 1).

In addition to affecting cell proliferation and survival, recent data suggest that dysregulation of PI3K/AKT pathway can upregulate the expression of known EMT inducers such as EZH2, BMI-1, Snail and Slug, ultimately promoting EMT and CSC features [41,42]. In immortalized mouse embryonic fibroblasts, PTEN loss results in elevated the levels of both EZH2 and BMI-1 [41]. AKT/Snail signaling activation is mechanistically associated with the acquisition of EMT/CSC properties in cisplatin-resistant lung cancer cells [42].

It has been become apparent that attenuated PTEN expression leads to constitutive activation of the PI3K/ AKT pathway, which consequently contributes to tumorigenesis and metastasis of EC. Homozygous deletion of PTEN in PTEN ${ }^{+/-}$mice leads to rapid formation of EC [43]. Consistent with this, conditional ablation of PTEN in mouse uterus is sufficient to activate the PI3K/AKT pathway and accelerate cancer cell invasiveness [44]. Furthermore, diminished AKT1 activity dramatically inhibits endometrial tumorigenesis caused by PTEN deficiency [45]. These reports indicate that hyperactivation of PI3K/ AKT due to PTEN loss is a key mechanism driving initiation and invasive growth of EC.

Loss of PTEN expression is more frequently associated with metastatic malignancy [46] and worse prognosis of patients with EC [47]. When PTEN gene is stably transfected into PTEN-mutated human EC cells, cell proliferation is markedly inhibited, accompanied by a decreased level of phosphorylated-AKT (p-AKT) expression [48]. Decreased p-AKT and increased apoptosis are detected in EC cells with mutated PTEN in the presence of PI3K inhibitor Wortmannin [49]. Collectively, these in vivo and in vitro evidence suggests that the role of PTEN loss-of-function in facilitating PI3K/AKT-dependent endometrial carcinogenesis and progression.

Moreover, in those ECs where PTEN protein is retained, mutations in $P I 3 K$ pathway members, such as PIK3CA, PIK3R1 (p85 $\alpha$ ) or PIK3R2 (p85ß), can functionally mimic the PTEN loss, resulting in marked increases in p-AKT levels [50]. Although KRAS mutations are common in endometrioid ECs, it seems that KRAS activates independent events from PI3K/AKT pathway aberrations [50]. Epidermal growth factor receptor (EGFR) acts upstream of PI3K/AKT signal [51] and could play an initiating role to stimulate EMT in EC cells via upregulating Snail protein expression [52]. Transient transfection of constitutively active form of AKT into uterine carcinosarcoma cells results in the transactivation of Slug, which in turns downregulates E-cadherin expression [53].

Taken together, these studies suggest that activation of the PI3K/AKT pathway (possibly through PTEN loss, PI3K mutations and EGFR activation) can trigger the invasive, EMT phenotypes of EC cells through modulating the expression of EMT inducer genes.

\section{Interactions between PI3K/AKT and other signaling molecules regulate EMT/CSC}

Oncogenes such as BMI-1 and EZH2 seem to act as both upstream regulators and downstream targets of PI3K/AKT pathway. The interactions between these EMT-inducing 


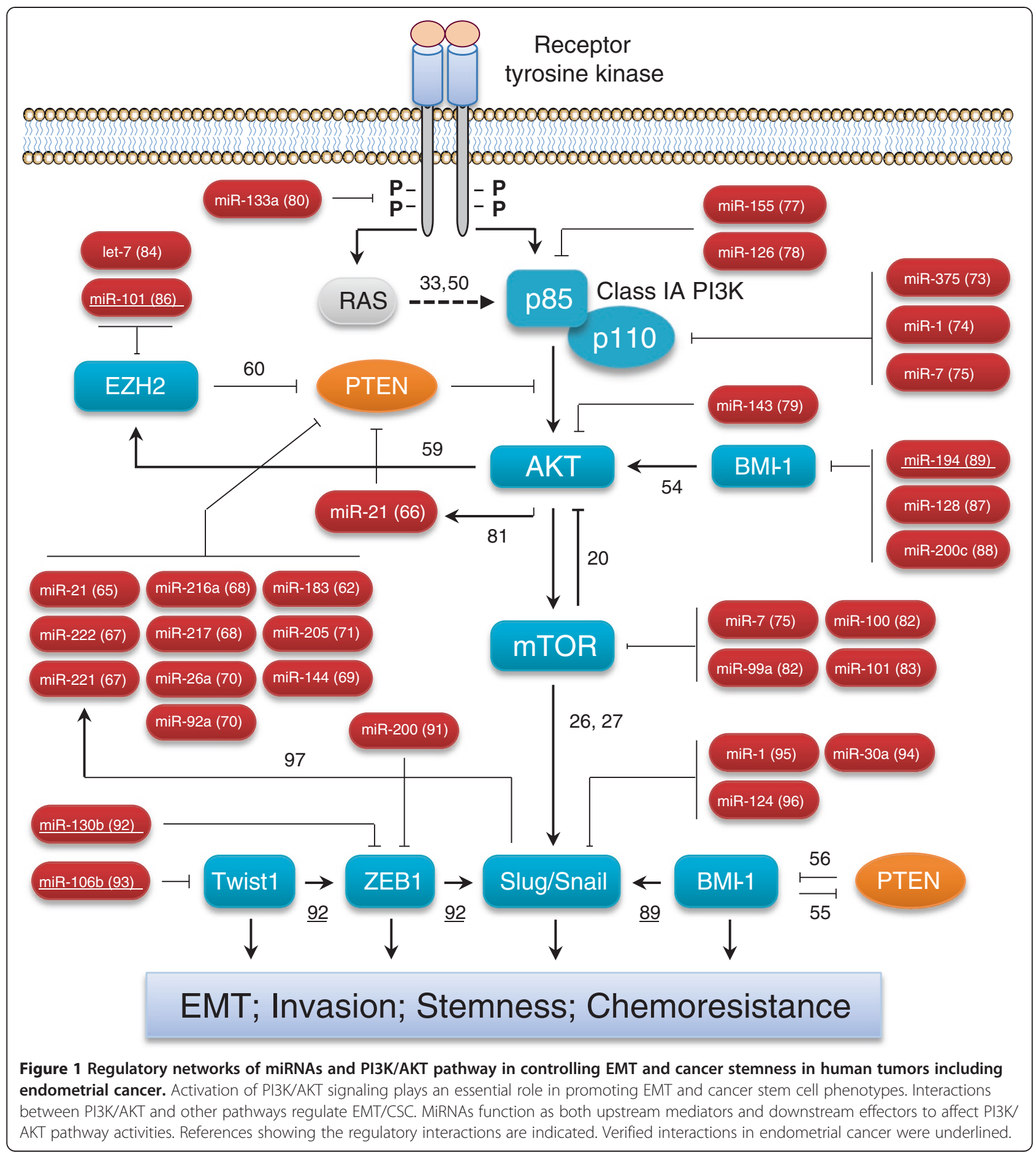

factors and PI3K/AKT pathway have been studied, and are required for the induction of EMT in tumor cells.

Overexpression of BMI-1 promotes resistance to cisplatin by increasing PI3K/AKT activity in osteosarcoma cells [54]. Likewise, another study of human nasopharyngeal epithelial cells suggest that BMI-1 transcriptionally downregulates the expression of PTEN and induces EMT through direct association with the PTEN locus
[55]. However, in prostate cancer cells, PTEN reduces the function of BMI-1 to prevent tumorigenesis, which can be attributed to its interaction with BMI-1 in the nucleus [56], indicating that a PTEN/BMI-1 doublenegative feedback loop may occur and govern EMT/CSC in certain types of cancer.

EZH2 has been reported to be required for CSC maintenance [57], and its overexpression often correlates with 
advanced stages and poor prognosis in diverse cancer types [58]. EZH2 has been identified as a downstream effector of PI3K/AKT pathway, and its depletion inhibits invasion and EMT in metastatic colon cancer cells [59]. However, in colon cancer stem cells the treatment with EZH2 inhibitor DZNep actually increased PTEN expression, decreased p-AKT expression and induced cell apoptosis [60]. These data suggest that the upregulation of EZH2 as a consequence of PI3K/AKT activation might increase PI3K/AKT activity by downregulating PTEN levels in CSC-like cell populations.

These studies demonstrate that feedback loops or cross-talks between PI3K/AKT pathway and other EMT/CSC-associated signaling are complex, and appear to be highly context-dependent. More studies are needed to characterize the relationship between PI3K/AKT and other important pathways in controlling EMT/CSC properties of EC cells (Figure 1).

\section{MiRNAs control EMT/CSC by targeting PI3K/AKT signaling in EC}

As miRNAs can bind to their mRNA targets with perfect or imperfect complementary, one miRNA may concurrently influence multiple target genes in the same pathway or different cellular signaling pathways [61]. Therefore, delivery of tumor suppressor miRNAs and/or silencing oncogenic miRNAs could be a promising way to rectify aberrations in the responsible signaling pathways related to EC.

Microarray-based miRNA profiling has been successfully performed to indentify a miRNA profile distinct from normal endometrium [62]. Dysregulated miRNA levels correlate with patient prognoses in EC [63]. Of importance, miRNAs have been reported to target multiple key components in the PI3K/AKT pathway in human tumors $[39,64]$ (Figure 1), as elaborated below.

\section{PTEN}

PTEN has been shown to be a direct target of miR-21 in human liver cancer [65]. Inhibition of miR-21 increases the expression of PTEN tumor suppressor, and decreases liver cancer cell proliferation, migration, and invasion [65]. Incidentally, miR-21 is also overexpressed in EC tissues, and downregulates PTEN expression via binding to the 3'-untranslated region (UTR) of PTEN mRNA, leading to promoted cell proliferation of EC cells [66]. In addition, miR-221 and miR-222, by targeting PTEN and raising $\mathrm{p}$-AKT expression, enhances cellular migration and tumorigenicity of lung and liver cancer cells [67]. MiR-261a/217 induces EMT and increases the stem-like cell population and metastatic ability of liver cancer cells by targeting PTEN [68]. MiR-144 was reported to increase cell proliferation, migration and invasion in nasopharyngeal carcinoma through repression of PTEN
[69]. Interestingly, miR-26a and miR-92a can promote cell proliferation of prostate cancer by regulating PTEN and its downstream PI3K/AKT signals [70]. MiR-205 interacts with PTEN $\mathrm{mRNA}$ and downregulates its expression in nasopharyngeal carcinoma cells [71]. MiR-205 expression is increased in ECs, and associated with decreased expression of PTEN and poorer patient overall survival [72]. This data implies a possible binding of miR-205 to PTEN 3'-UTR in EC cells. In another experiment, transfection of EC cells with miR-183 (a miRNA predicted to target PTEN) decreases PTEN protein expression [62]. However it is unclear whether miR-183 could directly suppress the 3'-UTR of PTEN in EC cells.

\section{PI3K}

In vivo and in vitro evidences support the tumor suppressor role for miR-375 in colorectal cancers [73]. MiR-375 levels are down-regulated in colorectal cancer cell lines and tissues [73]. The reporter assay confirms that miR375 inhibits colorectal cancer cell growth through the downregulation of PIK3CA expression [73]. MiR-1, which is downregulated in lung cancer cell, suppresses cancer cell proliferation, migration, and invasion by targeting PI3KCA and decreasing p-AKT levels [74]. Furthermore, overexpression of miR-7 inhibits liver cancer cell growth and metastasis in vitro and in vivo by suppressing PI3KCD (p1108) 3'-UTR [75]. PIK3R1 is mutated in 43\% of endometrioid ECs and 12\% of non-endometrioid ECs [76]. Expression of mutant PI3KR1 protein leads to constitutive activation of PI3K/AKT signal [76]. Study in diffuse large B-cell lymphoma cells suggests that PI3KR1 is a direct target of miR-155 [77]. MiR-126 expression is decreased in colon cancer cells when compared to normal human colon epithelia. Forced overexpression of miR-126 suppresses tumor cell growth by repressing PI3KR2 [78].

\section{AKT}

AKT is a direct target of miR-143 that mediates its growth inhibition effects in bladder cancer cells [79]. Additionally, miR-133a serves as a negative regulator of breast cancer cell proliferation through targeting EGFR, thereby indirectly suppresses the levels of p-AKT [80]. Some miRNAs can function as downstream effectors of AKT, as evidenced by the rapid downregulation of miR-21 following the inhibition of the AKT pathway in colon and breast cancer cells [81]. These findings indicate that miR-21 suppresses PTEN that decreases AKT activity, resulting in the up-regulation of miR-21. Thus, miR-21 might modulate AKT expression by forming a double-negative feedback loop involving tumor suppressor PTEN [81].

\section{mTOR}

Several miRNAs were shown to regulate mTOR in tumor cells, including miR-7 [75], miR-99a, miR-100 and miR- 
101. In childhood adrenocortical tumors, miR-99a and miR-100 directly target $m$ TOR 3 '-UTR, and the inhibition of mTOR signaling by Everolimus greatly attenuates tumor cell growth in vitro and in vivo [82]. Furthermore, introduction of miR-101 reduces anaplastic large-cell lymphoma cell proliferation though direct repressing mTOR [83].

\section{EMT inducers}

Numerous miRNAs act as negative regulators of EZH2, such as let-7 family members [84] and miR-101 [85]. Let-7 family members including let-7a, $-7 \mathrm{~b},-7 \mathrm{c}$ and $-7 \mathrm{~d}$ could strongly inhibit EZH2 3'-UTR luciferase activity, and repress clonogenic ability and sphere-forming capacity [84]. Restoration of miR-101 expression prevents the migration, invasion and proliferation of prostate cancer cells through the inhibition of EZH2 [85]. In aggressive EC cells, miR-101 has been found to inhibit EMT and CSC characteristics via a direct suppression of EZH2 [86]. BMI-1 is a direct target of miR-128 [87], miR-200c [88] and miR-194 [89]. These miRNAs block tumor cell self-renewal, drug resistance and metastasis. Expression levels of miR-194 are downregulated in ECs and associated with favorable survival [90]. Enforced expression of miR-194 inhibits EMT phenotype and EC cell invasion by targeting BMI-1 [89]. MiR-200 family members reverse the EMT features of breast cancer cells through repressing ZEB1 [91]. In EC cells, we previously identified 23 miRNAs that were downregulated by mutant p53 [92]. Among them, miR-130b, which is decreased in ECs relative to adjacent normal tissues, is capable of targeting the key EMT promoter gene ZEB1 and reverting mutant p53-induced EMT/CSC features of EC cells [92]. Another mutant p53-reponsive miR-106b can suppress EMT and cell invasion by modulating Twist1 in aggressive EC cells [93]. MiR-30a is downregulated in lung cancer and inhibits EMT by targeting Snail [94]. MiR-1 [95] or miR-124 [96] has been found to inhibit tumor cell invasion and EMT via regulation of Slug, which transactivates the promoter of oncogene miR-221 in breast cancer cells [97].

Collectively, dysregulation of miRNAs contributes to altered expression of multiple genes within the PI3K/ AKT pathway and are implicated in acquisition of invasive, EMT and CSC phenotype of tumor cells, supported by direct or indirect interactions between miRNAs and their target genes. However, studies evaluating the regulation of PI3K/AKT signal by miRNAs and therapeutic impact of miRNAs in EC are still rare.

\section{Combining miRNAs with PI3K/AKT inhibitors}

Members of PI3K/AKT signaling (PTEN and mTOR) are either feedback-regulated or cross-talks to other signaling cascades [98]. Therefore, drugs targeting the PI3K/
AKT pathway may more effectively treat tumors when used in combination with other targeted therapies, such as MEK inhibitors [99]. As certain miRNAs exhibit clear anti-tumor effects, one might expect the combining use of miRNAs and PI3K/AKT pathway inhibitors could enhance treatment efficacy. For example, overexpression of miR-100 coordinately represses the protein levels of mTOR and its upstream regulator FGFR3, and enhances the inhibitory effect of Everolimus on ovarian cancer cell viability [100]. In addition, a recent study suggests that the treatment of lymphoblastoid cells with mTOR inhibitors (Rapamycin and Everolimus) upregulates miR-10a expression, which in turn desensitizes cells to mTOR inhibitors response [101], indicating that miR-10a knockdown might improve the therapeutic effects of mTOR inhibitors. Thus, the combined use of PI3K/AKT inhibitors and miRNAs would be an attractive and possible therapeutic option.

\section{EMT and tumor growth}

A reversion of EMT, or MET is believed to allow tumor cells to restart their proliferation in the metastatic site [102]. Snail-induced EMT attenuates the cell cycle [103], and turning off Twist1 was found to increase proliferation in an in vivo skin tumor model [104]. However, Snail expression correlates with E-cadherin downregulation, actually increases proliferation in the hair bud where skin cells maintain the epithelial phenotype [105], thus the profound remodeling of the cytoskeleton (complete EMT) could be linked to decreased cell proliferation [106], whereas incomplete or transient activation of the EMT program might conversely induce cell proliferation. Consistent with this notion, complete and incomplete EMT phenotypes have been identified in human cancers, and associated with worse and relatively better survival rates, respectively $[107,108]$. Interestingly, EC cells undergo EMT tend to exhibit enhanced proliferation, invasiveness and cell scattering (rather than a complete conversion to a mesenchymal morphology) $[86,109,110]$, implying that a partial EMT program may often occur in EC cells. In addition, certain EMT inducer such as Twist1 cooperates with co-factors to promote tumor cell proliferation by abrogating cellular senescence [111]. These studies suggest that EMT processes, possibly induced by PI3K/AKT pathway, may confer increased EC cell invasion without inhibiting cell proliferation.

\section{Conclusions}

Growing evidence suggests that PI3K/AKT activation is vital to the induction of EMT and CSC properties in tumor cells. MiRNAs control cancer initiation, progression and metastasis, and function as both upstream mediators and downstream effectors to affect PI3K/AKT 
pathway activities. Introduction of tumor suppressive or knockdown of oncogenic miRNAs would be a promising approach to inhibiting the PI3K/AKT pathway in EC. The combination of miRNAs with PI3K/AKT inhibitors and inhibitors against other signals that cross-talk with PI3K/AKT pathway, might yield promising therapeutic effects.

Challenges of miRNA-based therapies in EC probably include the risk of unintended off-target effects [20], the necessity of eliminating CSC as well as non-CSC tumor cells [112], and the identification of alterations in the $3^{\prime}$ UTR of target gene, such as shortened $3^{\prime}$-UTR sequence and 3'-UTR mutations, which could disrupt the binding capacity of a certain miRNA [113-115]. Next-generation sequencing technologies have been used to identify some miRNAs that are expressed in a tissue-specific manner $[116,117]$, raising the possibility that tissue-specific miRNAs might be used to specifically target tumor cells and avoid off-target effects. Our new knowledge of the roles of miRNAs and their targets in regulating PI3K/AKT pathway will expand the utility of miRNAs for suppressing EMT and CSC in EC.

\section{Competing interests}

The authors declare that they have no competing interests.

\section{Authors' contributions}

PD wrote the manuscript. YK, HW, MH and NS assisted with the revision of English grammar and style. MN helped to prepare and revise the manuscript. All authors discussed the content and approved the final version of manuscript.

\section{Acknowledgements}

This work was funded by a grant from the Department of Women's Health Educational System, a Grant-in-Aid from the Ministry of Health, Labour and Welfare of Japan, and a Grant-in-Aid for Scientific Research (C) (24592496). We thank Professor Sun-Wei Guo (Shanghai Key Laboratory of Female Reproductive Endocrine Related Diseases, Shanghai, China) for critical review of the manuscript and many helpful discussions. We thank Dr. Zhujie Xu for help in preparing figure.

\section{Author details}

${ }^{1}$ Department of Women's Health Educational System, Hokkaido University School of Medicine, Hokkaido University, N15, W7, Sapporo 0608638, Japan. ${ }^{2}$ Department of Gynecology, Hokkaido University School of Medicine, Hokkaido University, N15, W7, Sapporo 0608638, Japan. ${ }^{3}$ Division of Cancer Biology Institute for Genetic Medicine, Hokkaido University, N15, W7, Sapporo 0608638, Japan.

Received: 28 June 2014 Accepted: 12 August 2014

Published: 21 August 2014

\section{References}

1. Siegel R, Ma J, Zou Z, Jemal A: Cancer statistics, 2014. CA Cancer J Clin 2014, 64:9-29.

2. Jin F, Devesa SS, Chow WH, Zheng W, Ji BT, Fraumeni JF Jr, Gao YT: Cancer incidence trends in urban shanghai, 1972-1994: an update. Int J Cancer 1999, 83:435-440.

3. Ushijima K: Current status of gynecologic cancer in Japan. $J$ Gynecol Oncol 2009, 20:67-71.

4. Bokhman JV: Two pathogenetic types of endometrial carcinoma. Gynecol Oncol 1983, 15:10-17.

5. Singh P, Smith CL, Cheetham G, Dodd TJ, Davy ML: Serous carcinoma of the uterus-determination of HER-2/neu status using immunohistochemistry, chromogenic in situ hybridization, and quantitative polymerase chain reaction techniques: its significance and clinical correlation. Int J Gynecol Cancer 2008, 18:1344-1351.

6. Alvarez T, Miller E, Duska L, Oliva E: Molecular profile of grade 3 endometrioid endometrial carcinoma: is it a type I or type II endometrial carcinoma? Am J Surg Pathol 2012, 36:753-761.

7. Mhawech-Fauceglia P, Wang D, Kesterson J, Syriac S, Clark K, Frederick PJ, Lele S, Liu S: Gene expression profiles in stage I uterine serous carcinoma in comparison to grade 3 and grade 1 stage I endometrioid adenocarcinoma. PLoS One 2011, 6:e18066.

8. Moore KN, Fader AN: Uterine papillary serous carcinoma. Clin Obstet Gynecol 2011, 54:278-291.

9. Slomovitz BM, Coleman RL: The PI3K/AKT/mTOR pathway as a therapeutic target in endometrial cancer. Clin Cancer Res 2012, 18:5856-5864.

10. Sarmadi S, Izadi-Mood N, Sotoudeh K, Tavangar SM: Altered PTEN expression; a diagnostic marker for differentiating normal, hyperplastic and neoplastic endometrium. Diagn Pathol 2009, 4:41.

11. Rudd ML, Price JC, Fogoros S, Godwin AK, Sgroi DC, Merino MJ, Bell DW: A unique spectrum of somatic PIK3CA (p110alpha) mutations within primary endometrial carcinomas. Clin Cancer Res 2011, 17:1331-1340.

12. Lacey JV Jr, Mutter GL, Ronnett BM, loffe OB, Duggan MA, Rush BB, Glass AG, Richesson DA, Chatterjee N, Langholz B, Sherman ME: PTEN expression in endometrial biopsies as a marker of progression to endometrial carcinoma. Cancer Res 2008, 68:6014-6020.

13. Matias-Guiu X, Prat J: Molecular pathology of endometrial carcinoma. Histopathology 2013, 62:111-123.

14. Acharya S, Hensley ML, Montag AC, Fleming GF: Rare uterine cancers. Lancet Oncol 2005, 6:961-971.

15. Zannoni GF, Scambia G, Gallo D: The dualistic model of endometrial cancer: the challenge of classifying grade 3 endometrioid carcinoma. Gynecol Oncol 2012, 127:262-263.

16. Yeramian A, Moreno-Bueno G, Dolcet X, Catasus L, Abal M, Colas E, Reventos J, Palacios J, Prat J, Matias-Guiu X: Endometrial carcinoma: molecular alterations involved in tumor development and progression. Oncogene 2013, 32:403-413.

17. Wild PJ, Ikenberg K, Fuchs TJ, Rechsteiner M, Georgiev S, Fankhauser N, Noske A, Roessle M, Caduff R, Dellas A, Fink D, Moch H, Krek W, Frew IJ: p53 suppresses type II endometrial carcinomas in mice and governs endometrial tumour aggressiveness in humans. EMBO Mol Med 2012, 4:808-824.

18. Nout RA, Bosse T, Creutzberg CL, Jürgenliemk-Schulz IM, Jobsen JJ, Lutgens LC, van der Steen-Banasik EM, van Eijk R, Ter Haar NT, Smit VT: Improved risk assessment of endometrial cancer by combined analysis of MSI, PI3K-AKT, Wnt/B-catenin and P53 pathway activation. Gynecol Oncol 2012, 126:466-473.

19. Kuhn E, Wu RC, Guan B, Wu G, Zhang J, Wang Y, Song L, Yuan X, Wei L, Roden RB, Kuo KT, Nakayama K, Clarke B, Shaw P, Olvera N, Kurman RJ, Levine DA, Wang TL, Shih IM: Identification of molecular pathway aberrations in uterine serous carcinoma by genome-wide analyses. J Natl Cancer Inst 2012, 104:1503-1513.

20. Dong P, Kaneuchi M, Konno Y, Watari H, Sudo S, Sakuragi N: Emerging therapeutic biomarkers in endometrial cancer. Biomed Res Int 2013, 2013:130362.

21. Chakrabarti R, Hwang J, Andres Blanco $M$, Wei $Y$, Lukačišin $M$, Romano RA Smalley K, Liu S, Yang Q, Ibrahim T, Mercatali L, Amadori D, Haffty BG, Sinha S, Kang Y: Elf5 inhibits the epithelial-mesenchymal transition in mammary gland development and breast cancer metastasis by transcriptionally repressing Snail2. Nat Cell Biol 2012, 14:1212-1222.

22. Larue L, Bellacosa A: Epithelial-mesenchymal transition in development and cancer: role of phosphatidylinositol 3' kinase/AKT pathways. Oncogene 2005, 24:7443-7454.

23. Chang L, Graham PH, Hao J, Bucci J, Cozzi PJ, Kearsley JH, Li Y: Emerging roles of radioresistance in prostate cancer metastasis and radiation therapy. Cancer Metastasis Rev. 2014, 33:469-496.

24. Mulholland DJ, Kobayashi N, Ruscetti M, Zhi A, Tran LM, Huang J, Gleave M, Wu H: Pten loss and RAS/MAPK activation cooperate to promote EMT and metastasis initiated from prostate cancer stem/progenitor cells. Cancer Res 2012, 72:1878-1889.

25. Molina JR, Hayashi Y, Stephens C, Georgescu MM: Invasive glioblastoma cells acquire stemness and increased Akt activation. Neoplasia 2010, 12:453-463. 
26. Chang L, Graham PH, Hao J, Ni J, Bucci J, Cozzi PJ, Kearsley JH, Li Y: Acquisition of epithelial-mesenchymal transition and cancer stem cell phenotypes is associated with activation of the PI3K/Akt/mTOR pathway in prostate cancer radioresistance. Cell Death Dis 2013, 4:e875.

27. Grille SJ, Bellacosa A, Upson J, Klein-Szanto AJ, van Roy F, Lee-Kwon W, Donowitz M, Tsichlis PN, Larue L: The protein kinase Akt induces epithelial mesenchymal transition and promotes enhanced motility and invasiveness of squamous cell carcinoma lines. Cancer Res 2003, 63:2172-2178

28. Aslam MI, Patel M, Singh B, Jameson JS, Pringle JH: MicroRNA manipulation in colorectal cancer cells: from laboratory to clinical application. J Trans/ Med 2012, 10:128.

29. Matsushima K, Isomoto H, Yamaguchi N, Inoue N, Machida H, Nakayama T, Hayashi T, Kunizaki M, Hidaka S, Nagayasu T, Nakashima M, Ujifuku K, Mitsutake N, Ohtsuru A, Yamashita S, Korpal M, Kang Y, Gregory PA, Goodall GJ, Kohno S, Nakao K: MiRNA-205 modulates cellular invasion and migration via regulating zinc finger E-box binding homeobox 2 expression in esophageal squamous cell carcinoma cells. J Trans/ Med 2011, 9:30.

30. Luo X, Dong Z, Chen Y, Yang L, Lai D: Enrichment of ovarian cancer stem-like cells is associated with epithelial to mesenchymal transition through an miRNA-activated AKT pathway. Cell Prolif 2013, 46:436-446.

31. Zhao L, Vogt PK: Class I PI3K in oncogenic cellular transformation. Oncogene 2008, 27:5486-5496.

32. Courtney KD, Corcoran RB, Engelman JA: The PI3K pathway as drug target in human cancer. J Clin Oncol 2010, 28:1075-1083.

33. Engelman JA: Targeting PI3K signalling in cancer: opportunities, challenges and limitations. Nat Rev Cancer 2009, 9:550-562.

34. Steelman LS, Chappell WH, Abrams SL, Kempf RC, Long J, Laidler P, Mijatovic S, Maksimovic-Ivanic D, Stivala F, Mazzarino MC, Donia M, Fagone P, Malaponte G, Nicoletti F, Libra M, Milella M, Tafuri A, Bonati A, Bäsecke J, Cocco L, Evangelisti C, Martelli AM, Montalto G, Cervello M, McCubrey JA: Roles of the Raf/MEK/ERK and PI3K/PTEN/Akt/mTOR pathways in controlling growth and sensitivity to therapy-implications for cancer and aging. Aging (Albany NY) 2011, 3:192-222.

35. Davies MA: Regulation, role, and targeting of Akt in cancer. J Clin Oncol 2011, 29:4715-4717.

36. Yoeli-Lerner M, Yiu GK, Rabinovitz I, Erhardt P, Jauliac S, Toker A: Akt blocks breast cancer cell motility and invasion through the transcription factor NFAT. Mol Cell 2005, 20:539-550.

37. Irie HY, Pearline RV, Grueneberg D, Hsia M, Ravichandran P, Kothari N, Natesan S, Brugge JS: Distinct roles of Akt1 and Akt2 in regulating cell migration and epithelial-mesenchymal transition. J Cell Biol 2005, 171:1023-1034.

38. Girouard J, Lafleur MJ, Parent S, Leblanc V, Asselin E: Involvement of Akt isoforms in chemoresistance of endometrial carcinoma cells. Gynecol Oncol 2013, 128:335-343.

39. Alqurashi N, Hashimi SM, Wei MQ: Chemical inhibitors and microRNAs (miRNA) targeting the mammalian target of rapamycin (mTOR) pathway: potential for novel anticancer therapeutics. Int J Mol Sci 2013, 14:3874-3900

40. Gulhati P, Bowen KA, Liu J, Stevens PD, Rychahou PG, Chen M, Lee EY, Weiss HL, O'Connor KL, Gao T, Evers BM: mTORC1 and $\mathrm{mTORC2}$ regulate EMT, motility, and metastasis of colorectal cancer via RhoA and Rac1 signaling pathways. Cancer Res 2011, 71:3246-33256.

41. Zeng N, Yang KT, Bayan JA, He L, Aggarwal R, Stiles JW, Hou X, Medina V, Abad D, Palian BM, Al-Abdullah I, Kandeel F, Johnson DL, Stiles BL: PTEN controls $\beta$-cell regeneration in aged mice by regulating cell cycle inhibitor p16ink4a. Aging Cell 2013, 12:1000-1011.

42. Wang H, Zhang G, Zhang H, Zhang F, Zhou B, Ning F, Wang HS, Cai SH, Du J: Acquisition of epithelial-mesenchymal transition phenotype and cancer stem cell-like properties in cisplatin-resistant lung cancer cells through AKT/ß-catenin/Snail signaling pathway. Eur J Pharmacol 2014, 723:156-166.

43. Daikoku T, Hirota Y, Tranguch S, Joshi AR, DeMayo FJ, Lydon JP, Ellenson LH, Dey SK: Conditional loss of uterine Pten unfailingly and rapidly induces endometrial cancer in mice. Cancer Res 2008, 68:5619-5627.

44. Lindberg ME, Stodden GR, King ML, MacLean JA 2nd, Mann JL, DeMayo FJ, Lydon JP, Hayashi K: Loss of CDH1 and Pten accelerates cellular invasiveness and angiogenesis in the mouse uterus. Biol Reprod 2013, 89:8.
45. Chen ML, Xu PZ, Peng XD, Chen WS, Guzman G, Yang X, Di Cristofano A, Pandolfi PP, Hay N: The deficiency of Akt1 is sufficient to suppress tumor development in Pten+/- mice. Genes Dev 2006, 20:1569-1574.

46. Salvesen HB, Stefansson I, Kalvenes MB, Das S, Akslen LA: Loss of PTEN expression is associated with metastatic disease in patients with endometrial carcinoma. Cancer 2002, 94:2185-2191.

47. Terakawa N, Kanamori Y, Yoshida S: Loss of PTEN expression followed by Akt phosphorylation is a poor prognostic factor for patients with endometrial cancer. Endocr Relat Cancer 2003, 10:203-208.

48. Uegaki K, Kanamori Y, Kigawa J, Kawaguchi W, Kaneko R, Naniwa J, Takahashi M, Shimada M, Oishi T, Itamochi H, Terakawa N: PTEN is involved in the signal transduction pathway of contact inhibition in endometrial cells. Cell Tissue Res 2006, 323:523-528.

49. Gagnon V, St-Germain ME, Parent S, Asselin E: Akt activity in endometrial cancer cells: regulation of cell survival through cIAP-1. Int J Oncol 2003, 23:803-810.

50. Cheung LW, Hennessy BT, Li J, Yu S, Myers AP, Djordjevic B, Lu Y, Stemke-Hale K, Dyer MD, Zhang F, Ju Z, Cantley LC, Scherer SE, Liang H, Lu KH, Broaddus RR, Mills GB: High frequency of PIK3R1 and PIK3R2 mutations in endometrial cancer elucidates a novel mechanism for regulation of PTEN protein stability. Cancer Discov 2011, 1:170-185.

51. Dong $P, X u Z$, Jia N, Li D, Feng Y: Elevated expression of p53 gain-of-function mutation $\mathrm{R} 175 \mathrm{H}$ in endometrial cancer cells can increase the invasive phenotypes by activation of the EGFR/PI3K/AKT pathway. Mol Cancer 2009, 8:103.

52. Hipp S, Walch A, Schuster T, Losko S, Laux H, Bolton T, Höfler H, Becker KF: Activation of epidermal growth factor receptor results in snail protein but not mRNA overexpression in endometrial cancer. J Cell Mol Med 2009, 13:3858-3867.

53. Saegusa M, Hashimura M, Kuwata T, Okayasu I: Requirement of the Akt/ beta-catenin pathway for uterine carcinosarcoma genesis, modulating E-cadherin expression through the transactivation of slug. Am J Pathol 2009, 174:2107-2115.

54. Wu Z, Min L, Chen D, Hao D, Duan Y, Qiu G, Wang Y: Overexpression of BMI-1 promotes cell growth and resistance to cisplatin treatment in osteosarcoma. PLoS One 2011, 6:e14648.

55. Song LB, Li J, Liao WT, Feng Y, Yu CP, Hu LJ, Kong QL, Xu LH, Zhang X, Liu WL, Li MZ, Zhang L, Kang TB, Fu LW, Huang WL, Xia YF, Tsao SW, Li M, Band V, Band H, Shi QH, Zeng YX, Zeng MS: The polycomb group protein Bmi-1 represses the tumor suppressor PTEN and induces epithelial-mesenchymal transition in human nasopharyngeal epithelial cells. J Clin Invest 2009, 119:3626-3636.

56. Fan C, He L, Kapoor A, Rybak AP, De Melo J, Cutz JC, Tang D: PTEN inhibits BMI1 function independently of its phosphatase activity. Mol Cancer 2009, 8:98.

57. van Vlerken LE, Kiefer CM, Morehouse C, Li Y, Groves C, Wilson SD, Yao Y, Hollingsworth RE, Hurt EM: EZH2 is required for breast and pancreatic cancer stem cell maintenance and can be used as a functional cancer stem cell reporter. Stem Cells Transl Med 2013, 2:43-52.

58. Crea F, Fornaro L, Bocci G, Sun L, Farrar WL, Falcone A, Danesi R: EZH2 inhibition: targeting the crossroad of tumor invasion and angiogenesis. Cancer Metastasis Rev 2012, 31:753-761.

59. Ferraro A, Mourtzoukou D, Kosmidou V, Avlonitis S, Kontogeorgos G, Zografos $G$, Pintzas A: EZH2 is regulated by ERK/AKT and targets integrin alpha2 gene to control Epithelial-Mesenchymal Transition and anoikis in colon cancer cells. Int J Biochem Cell Biol 2013, 45:243-254.

60. Benoit YD, Witherspoon MS, Laursen KB, Guezguez A, Beauséjour M, Beaulieu JF, Lipkin SM, Gudas LJ: Pharmacological inhibition of polycomb repressive complex-2 activity induces apoptosis in human colon cancer stem cells. Exp Cell Res 2013, 319:1463-1470.

61. Bartel DP: MicroRNAs: genomics, biogenesis, mechanism, and function. Cell 2004, 116:281-297.

62. Cohn DE, Fabbri M, Valeri N, Alder H, Ivanov I, Liu CG, Croce CM, Resnick KE: Comprehensive miRNA profiling of surgically staged endometrial cancer. Am J Obstet Gynecol 2010, 202:656.e1-8.

63. Hiroki E, Akahira J, Suzuki F, Nagase S, Ito K, Suzuki T, Sasano H, Yaegashi N: Changes in microRNA expression levels correlate with clinicopathological features and prognoses in endometrial serous adenocarcinomas. Cancer Sci 2010, 101:241-249.

64. Mlcochova J, Faltejskova P, Nemecek R, Svoboda M, Slaby O: MicroRNAs targeting EGFR signalling pathway in colorectal cancer. J Cancer Res Clin Oncol 2013, 139:1615-1624. 
65. Meng F, Henson R, Wehbe-Janek H, Ghoshal K, Jacob ST, Patel T: MicroRNA-21 regulates expression of the PTEN tumor suppressor gene in human hepatocellular cancer. Gastroenterology 2007, 133:647-658.

66. Qin X, Yan L, Zhao X, Li C, Fu Y: microRNA-21 overexpression contributes to cell proliferation by targeting PTEN in endometrioid endometrial cancer. Oncol Lett 2012, 4:1290-1296.

67. Garofalo M, Di Leva G, Romano G, Nuovo G, Suh SS, Ngankeu A, Taccioli C, Pichiorri F, Alder H, Secchiero P, Gasparini P, Gonelli A, Costinean S, Acunzo M, Condorelli G, Croce CM: miR-221\&222 regulate TRAIL resistance and enhance tumorigenicity through PTEN and TIMP3 downregulation. Cancer Cell 2009, 16:498-509.

68. Xia H, Ooi LL, Hui KM: MicroRNA-216a/217-induced epithelialmesenchymal transition targets PTEN and SMAD7 to promote drug resistance and recurrence of liver cancer. Hepatology 2013, 58:629-641.

69. Zhang LY, Ho-Fun Lee V, Wong AM, Kwong DL, Zhu YH, Dong SS, Kong KL, Chen J, Tsao SW, Guan XY, Fu L: MicroRNA-144 promotes cell proliferation, migration and invasion in nasopharyngeal carcinoma through repression of PTEN. Carcinogenesis 2013, 34:454-463.

70. Tian L, Fang $Y X$, Xue JL, Chen JZ: Four microRNAs promote prostate cell proliferation with regulation of PTEN and its downstream signals in vitro. PLoS One 2013, 8:e75885.

71. Qu C, Liang Z, Huang J, Zhao R, Su C, Wang S, Wang X, Zhang R, Lee MH, Yang H: MiR-205 determines the radioresistance of human nasopharyngeal carcinoma by directly targeting PTEN. Cell Cycle 2012, 11:785-796.

72. Karaayvaz M, Zhang C, Liang S, Shroyer KR, Ju J: Prognostic significance of miR-205 in endometrial cancer. PLOS One 2012, 7:e35158.

73. Wang Y, Tang Q, Li M, Jiang S, Wang X: MicroRNA-375 inhibits colorectal cancer growth by targeting PIK3CA. Biochem Biophys Res Commun 2014, 444:199-204.

74. Yu QQ, Wu H, Huang X, Shen H, Shu YQ, Zhang B, Xiang CC, Yu SM, Guo $\mathrm{RH}$, Chen L: MiR-1 targets PIK3CA and inhibits tumorigenic properties of A549 cells. Biomed Pharmacother 2014, 68:155-161.

75. Fang Y, Xue JL, Shen Q, Chen J, Tian L: MicroRNA-7 inhibits tumor growth and metastasis by targeting the phosphoinositide 3-kinase/Akt pathway in hepatocellular carcinoma. Hepatology 2012, 55:1852-1862.

76. Urick ME, Rudd ML, Godwin AK, Sgroi D, Merino M, Bell DW: PIK3R1 (p85a) is somatically mutated at high frequency in primary endometrial cancer. Cancer Res 2011, 71:4061-4067.

77. Huang X, Shen Y, Liu M, Bi C, Jiang C, Iqbal J, McKeithan TW, Chan WC, Ding SJ, Fu K: Quantitative proteomics reveals that miR-155 regulates the PI3K-AKT pathway in diffuse large B-cell lymphoma. Am J Pathol 2012, 181:26-33.

78. Guo C, Sah JF, Beard L, Willson JK, Markowitz SD, Guda K: The noncoding RNA, miR-126, suppresses the growth of neoplastic cells by targeting phosphatidylinositol 3-kinase signaling and is frequently lost in colon cancers. Genes Chromosomes Cancer 2008, 47:939-946.

79. Noguchi S, Yasui Y, Iwasaki J, Kumazaki M, Yamada N, Naito S, Akao Y: Replacement treatment with microRNA-143 and -145 induces synergistic inhibition of the growth of human bladder cancer cells by regulating $\mathrm{PI} 3 \mathrm{~K}$ J Akt and MAPK signaling pathways. Cancer Lett 2013, 328:353-361.

80. Cui W, Zhang S, Shan C, Zhou L, Zhou Z: microRNA-133a regulates the cell cycle and proliferation of breast cancer cells by targeting epidermal growth factor receptor through the EGFR/Akt signaling pathway. FEBS J 2013, 280:3962-3974.

81. Sayed D, Abdellatif M: AKT-ing via microRNA. Cell Cycle 2010, 9:3213-3217.

82. Doghman M, El Wakil A, Cardinaud B, Thomas E, Wang J, Zhao W, Peralta-Del Valle MH, Figueiredo BC, Zambetti GP, Lalli E: Regulation of insulin-like growth factor-mammalian target of rapamycin signaling by microRNA in childhood adrenocortical tumors. Cancer Res 2010, 70:4666-4675.

83. Merkel O, Hamacher F, Laimer D, Sifft E, Trajanoski Z, Scheideler M, Egger G, Hassler MR, Thallinger C, Schmatz A, Turner SD, Greil R, Kenner L: Identification of differential and functionally active miRNAs in both anaplastic lymphoma kinase (ALK)+ and ALK- anaplastic large-cell lymphoma. Proc Natl Acad Sci U S A 2010, 107:16228-16233.

84. Kong D, Heath E, Chen W, Cher ML, Powell I, Heilbrun L, Li Y, Ali S, Sethi S, Hassan O, Hwang C, Gupta N, Chitale D, Sakr WA, Menon M, Sarkar FH: Loss of let-7 up-regulates $\mathrm{EZH} 2$ in prostate cancer consistent with the acquisition of cancer stem cell signatures that are attenuated by BR-DIM. PLoS One 2012, 7:e33729.

85. Cao P, Deng Z, Wan M, Huang W, Cramer SD, Xu J, Lei M, Sui G: MicroRNA-101 negatively regulates Ezh2 and its expression is modulated by androgen receptor and HIF-1alpha/HIF-1beta. Mol Cancer 2010, 9:108.
86. Konno $Y$, Dong $P$, Xiong $Y$, Suzuki F, Lu J, Cai M, Watari H, Mitamura T, Hosaka M, Hanley SJ, Kudo M, Sakuragi N: MicroRNA-101 targets EZH2, MCL-1 and FOS to suppress proliferation, invasion and stem cell-like phenotype of aggressive endometrial cancer cells. Oncotarget 2014, [Epub ahead of print].

87. Godlewski J, Nowicki MO, Bronisz A, Williams S, Otsuki A, Nuovo G, Raychaudhury A, Newton HB, Chiocca EA, Lawler S: Targeting of the Bmi-1 oncogene/stem cell renewal factor by microRNA-128 inhibits glioma proliferation and self-renewal. Cancer Res 2008, 68:9125-9130.

88. Liu S, Tetzlaff MT, Cui R, Xu X: miR-200c inhibits melanoma progression and drug resistance through down-regulation of BMI-1. Am J Pathol 2012, 181:1823-1835.

89. Dong P, Kaneuchi M, Watari H, Hamada J, Sudo S, Ju J, Sakuragi N: MicroRNA-194 inhibits epithelial to mesenchymal transition of endometrial cancer cells by targeting oncogene BMI-1. Mol Cancer 2011, 10:99-108.

90. Zhai H, Karaayvaz M, Dong P, Sakuragi N, Ju J: Prognostic significance of miR-194 in endometrial cancer. Biomarker Research 2013, 1:12.

91. Gregory PA, Bert AG, Paterson EL, Barry SC, Tsykin A, Farshid G, Vadas MA, Khew-Goodall Y, Goodall GJ: The miR-200 family and miR-205 regulate epithelial to mesenchymal transition by targeting ZEB1 and SIP1. Nat Cell Biol 2008, 10:593-601.

92. Dong P, Karaayvaz M, Jia N, Kaneuchi M, Hamada J, Watari H, Sudo S, Ju J, Sakuragi N: Mutant p53 gain-of-function induces epithelial-mesenchymal transition through modulation of the miR-130b-ZEB1 axis. Oncogene 2013, 32:3286-3295.

93. Dong P, Kaneuchi M, Watari H, Sudo S, Sakuragi N: MicroRNA-106b modulates epithelial-mesenchymal transition by targeting TWIST1 in invasive endometrial cancer cell lines. Mol Carcinog 2014, 53:349-359.

94. Kumarswamy R, Mudduluru G, Ceppi P, Muppala S, Kozlowski M, Niklinski J, Papotti M, Allgayer H: MicroRNA-30a inhibits epithelial-to-mesenchymal transition by targeting Snai1 and is downregulated in non-small cell lung cancer. Int J Cancer 2012, 130:2044-2053.

95. Tominaga E, Yuasa K, Shimazaki S, Hijikata T: MicroRNA-1 targets Slug and endows lung cancer A549 cells with epithelial and anti-tumorigenic properties. Exp Cell Res 2013, 319:77-88

96. Liang YJ, Wang QY, Zhou CX, Yin QQ, He M, Yu XT, Cao DX, Chen GQ, He JR, Zhao Q: MiR-124 targets Slug to regulate epithelial-mesenchymal transition and metastasis of breast cancer. Carcinogenesis 2013, 34:713-722.

97. Lambertini E, Lolli A, Vezzali F, Penolazzi L, Gambari R, Piva R: Correlation between slug transcription factor and miR-221 in MDA-MB-231 breast cancer cells. BMC Cancer 2012, 12:445.

98. Carracedo A, Pandolfi PP: The PTEN-PI3K pathway: of feedbacks and cross-talks. Oncogene 2008, 27:5527-5541.

99. Guenther MK, Graab U, Fulda S: Synthetic lethal interaction between PI3K/ Akt/mTOR and Ras/MEK/ERK pathway inhibition in rhabdomyosarcoma. Cancer Lett 2013, 337:200-209.

100. Nagaraja AK, Creighton CJ, Yu Z, Zhu H, Gunaratne PH, Reid JG, Olokpa E, Itamochi H, Ueno NT, Hawkins SM, Anderson ML, Matzuk MM: A link between mir-100 and FRAP1/mTOR in clear cell ovarian cancer. Mol Endocrinol 2010, 24:447-463.

101. Jiang J, Fridley BL, Feng Q, Abo RP, Brisbin A, Batzler A, Jenkins G, Long PA, Wang $L$ : Genome-wide association study for biomarker identification of rapamycin and Everolimus using a lymphoblastoid cell line system. Front Genet 2013, 4:166.

102. Tsai JH, Yang J: Epithelial-mesenchymal plasticity in carcinoma metastasis. Genes Dev 2013, 27:2192-2206.

103. Vega S, Morales AV, Ocaña OH, Valdés F, Fabregat I, Nieto MA: Snail blocks the cell cycle and confers resistance to cell death. Genes Dev 2004, 18:1131-1143.

104. Tsai JH, Donaher JL, Murphy DA, Chau S, Yang J: Spatiotemporal regulation of epithelial-mesenchymal transition is essential for squamous cell carcinoma metastasis. Cancer Cell 2012, 22:725-736.

105. Jamora C, Lee $P$, Kocieniewski $P$, Azhar M, Hosokawa R, Chai Y, Fuchs E: A signaling pathway involving TGF-beta2 and snail in hair follicle morphogenesis. PLOS Biol 2005, 3:e11.

106. Barrallo-Gimeno A, Nieto MA: The Snail genes as inducers of cell movement and survival: implications in development and cancer. Development 2005, 132:3151-3161.

107. Bae YK, Kim A, Choi JE, Kang SH, Lee SJ: Epithelial-mesenchymal transition phenotype in breast cancers is associated with clinicopathologic factors 
indicating aggressive biologic behavior and poor clinical outcome. Cancer Res 2012, 72(24 Suppl):Abstract nr P5-04-07.

108. Huang RY, Wong MK, Tan TZ, Kuay KT, Ng AH, Chung VY, Chu YS, Matsumura N, Lai HC, Lee YF, Sim WJ, Chai C, Pietschmann E, Mori S, Low JJ, Choolani M, Thiery JP: An EMT spectrum defines an anoikis-resistant and spheroidogenic intermediate mesenchymal state that is sensitive to e-cadherin restoration by a src-kinase inhibitor, saracatinib (AZD0530). Cell Death Dis 2013, 4:e915.

109. Xie R, Schlumbrecht MP, Shipley GL, Xie S, Bassett RL Jr, Broaddus RR: S100A4 mediates endometrial cancer invasion and is a target of TGF-beta1 signaling. Lab Invest. 2009, 89:937-947.

110. Dong P, Kaneuchi M, Xiong Y, Cao L, Cai M, Liu X, Guo SW, Ju J, Jia N, Konno Y, Watari H, Hosaka M, Sudo S, Sakuragi N: Identification of KLF17 as a novel epithelial to mesenchymal transition inducer via direct activation of TWIST1 in endometrioid endometrial cancer. Carcinogenesis 2014, 35:760-768.

111. Tran PT, Shroff EH, Burns TF, Thiyagarajan S, Das ST, Zabuawala T, Chen J, Cho YJ, Luong R, Tamayo P, Salih T, Aziz K, Adam SJ, Vicent S, Nielsen CH, Withofs N, Sweet-Cordero A, Gambhir SS, Rudin CM, Felsher DW: Twist1 suppresses senescence programs and thereby accelerates and maintains mutant Kras-induced lung tumorigenesis. PLoS Genet 2012, 8:e1002650.

112. Liu S, Patel SH, Ginestier C, Ibarra I, Martin-Trevino R, Bai S, McDermott SP, Shang L, Ke J, Ou SJ, Heath A, Zhang KJ, Korkaya H, Clouthier SG, Charafe-Jauffret E, Birnbaum D, Hannon GJ, Wicha MS: MicroRNA93 regulates proliferation and differentiation of normal and malignant breast stem cells. PLoS Genet 2012, 8:e1002751.

113. Sandberg R, Neilson JR, Sarma A, Sharp PA, Burge CB: Proliferating cells express mRNAs with shortened $3^{\prime}$ untranslated regions and fewer microRNA target sites. Science 2008, 320:1643-1647.

114. Chin LJ, Ratner E, Leng S, Zhai R, Nallur S, Babar I, Muller RU, Straka E, Su L, Burki EA, Crowell RE, Patel R, Kulkarni T, Homer R, Zelterman D, Kidd KK, Zhu Y, Christiani DC, Belinsky SA, Slack FJ, Weidhaas JB: A SNP in a let-7 microRNA complementary site in the KRAS $3^{\prime}$ untranslated region increases non-small cell lung cancer risk. Cancer Res 2008, 68:8535-8540.

115. Arcaroli JJ, Quackenbush KS, Powell RW, Pitts TM, Spreafico A, Varella-Garcia M, Bemis L, Tan AC, Reinemann JM, Touban BM, Dasari A, Eckhardt SG, Messersmith WA: Common PIK3CA mutants and a novel 3' UTR mutation are associated with increased sensitivity to saracatinib. Clin Cancer Res 2012, 18:2704-2714.

116. Perdomo C, Campbell JD, Gerrein J, Tellez CS, Garrison CB, Walser TC, Drizik E, Si H, Gower AC, Vick J, Anderlind C, Jackson GR, Mankus C, Schembri F, O'Hara C, Gomperts BN, Dubinett SM, Hayden P, Belinsky SA, Lenburg ME, Spira A: MicroRNA 4423 is a primate-specific regulator of airway epithelial cell differentiation and lung carcinogenesis. Proc Nat Acad Sci U S A 2013, 110:18946-18951.

117. Hu R, Pan W, Fedulov AV, Jester W, Jones MR, Weiss ST, Panettieri RA Jr, Tantisira K, Lu Q: MicroRNA-10a controls airway smooth muscle cell proliferation via direct targeting of the PI3 kinase pathway. FASEB J 2014, 28:2347-2357.

doi:10.1186/s12967-014-0231-0

Cite this article as: Dong et al:: The impact of microRNA-mediated PI3K/ AKT signaling on epithelial-mesenchymal transition and cancer stemness in endometrial cancer. Journal of Translational Medicine 2014 12:231.

\section{Submit your next manuscript to BioMed Central and take full advantage of:}

- Convenient online submission

- Thorough peer review

- No space constraints or color figure charges

- Immediate publication on acceptance

- Inclusion in PubMed, CAS, Scopus and Google Scholar

- Research which is freely available for redistribution 